\title{
Fostering Productive Thinking Among Elementary School Students Through FIESI Model
}

\author{
Ashutosh Biswal ${ }^{1}$ and Kamakshi Raipure ${ }^{2}$ \\ ${ }^{1,2}$ Department of Education (CASE), The Maharaja Sayajirao University of Baroda, Vadodara-390002, India \\ 1ab9825668982@gmail.com (Corresponding Author) \\ ²kamakshidavv@gmail.com
}

\section{ARTICLE INFORMATION}

Received: September 04, 2020

Revised: September 28, 2020

Accepted: October 05, 2020

Published Online: October 21, 2020

\section{Keywords:}

Creative thinking, Critical thinking,

Reproductive thinking, Productive thinking, FIESI model

DOI: $10.15415 /$ iie.2020.82008

\begin{abstract}
Productive thinking is the cognitive ability to plan, reason logically, analyse, synthesize, evaluate, and make decision to reach at the solution of the problem or we can say that it is the ability by which one can refine their creative work with critical thinking to give strength and value to it. It is a way to solve problems creatively. For this research, a model has been developed called as FIESI (Foundation, Ideation, Evaluation, Stabilization and Implication) for fostering productive thinking. Researchers conducted an experiment to foster productive thinking among VIII standard students with the help of this model as elementary level is delimited to standard VIII. Quasi-experimental pre-test post-test control group design was used. Two Kendriya Vidyalayas (Central Schools) were selected purposively for experiment purpose. One section of standard VIII from each school was selected as the sample for the experiment and control groups. Students of both the classes were made equivalent on the basis of a science achievement test. The equivalent groups consist of 26 students each. Researchers taught Science to the experimental group for one academic year (2019-2020) using FIESI model and the control group was taught by their regular teachers. Researchers developed and validated a productive thinking test for data collection. Data were analysed using chi-square. The finding revealed that FIESI model was found significant in fostering productive thinking among standard VIII students.
\end{abstract}

\section{Introduction}

India's primary school enrolment has come close to being universal and literacy rates have risen encouragingly in recent times. However, Indian achievements in other respects leave much to be desired. Learning achievements in both primary and secondary schooling are low, signaling poor-quality schooling (Kingdon, 2007). Majority of secondary school students were at lower order thinking level and need to improve their higher order thinking skills especially synthesis and evaluation skills required for improving students productivity (Saido et al., 2015). Students scored good marks in examinations conducted by school or affiliated board but most of the students don't get good marks at the entrance examinations based on higher order thinking. This gap in performance indicates serious deficiencies in the students' thinking and reasoning. There is a need to revamp our education system, particularly our school education to inculcate higher order thinking among the youth. The current National Education Policy (2020) rightly emphasized that one of the fundamental principles that will guide both the education system at large as well as the individual institutions within it is creative and critical thinking to encourage logical decision making and innovation. To address this gap we need to restructure our classroom atmosphere where the use of triadic dialogue in questioning has been well reported i.e. "I-R-F" (Initiation, Response and Feedback). This three step pattern as typical of traditional teaching restrict thinking and lead to rote learning (Newton, 2017). NCERT position paper (2006) reported that there is too much emphasis on drill and rote learning and too little emphasis on observation, design, analysis, and argumentation and process skills. Instead of a culture of quizzing of answering quickly and always knowing the right answer, we need to allow learners to spend time on deeper, meaningful learning (NCF, 2005). For meaningful learning in today's classroom we need two skills retention and transfer. Retention means students remember what they have learned, whereas transfer requires students not only to remember but also to make sense of and be able to use what they 
have learned (Mayer, 2002). It is evident that Bloom's taxonomy provides variety of teaching experiences ranges from lower to higher order thinking level. Most of the teaching objectives in the classroom are oriented towards knowledge level only dominated by left brain and we are not creating situations to develop the full brain potential of the child. It should be modified in such a way that there is a place for developing right brain and both hemisphere cooperate for the full potential of human brain (Gill, 1989).

Classroom environment and teaching strategy dominated by rote learning and authoritative discourse which lead to reproductive thinking (rote learning) will not train our students for $21^{\text {st }}$ century challenges. It is rightly stressed in the World Economic Forum report, The Future of Jobs (2016). Out of the 10 skills identified for the youth for the present fourth industrial revolution according to this report, five skills are directly related to thinking, i.e. Complex Problem Solving, Critical Thinking, Creativity, Emotional Intelligence and Judgement and Decision Making. It shows the importance of incorporating thinking in the process of education. It is the time to revamp our classroom environment and teaching learning process for thinking particularly by harnessing productive thinking on the base of reproductive thinking as productive thinking includes most of the types of thinking. Birch and Rabinowitz (1951) described reproductive thinking as solving a novel problem using previously mastered skills or by the use of chained behavior, whereas, productive thinking is solving problem by restructuring or changing the patterns of past experience to meet the current demands. Further, productive thinking can be defined as the cognitive ability to plan, reason logically, analyse, synthesize, evaluate, and make decision to reach at the solution of the problem. In the present research, researchers made an attempt to develop a thinking model called FIESI (Foundation, Ideation, Evaluation, Stabilization and Implication) model for fostering productive thinking among school students through teaching of different subjects as this is the right age where foundation for the secondary and higher secondary schooling is made and students are also ready for abstract thinking according to Piaget cognitive development model. Researchers experimented this model in the teaching of Science subject as Saido et al. (2015) suggested that in science education, students should have the opportunity to begin thinking like scientists by engaging them in the process of thinking instead of merely ingesting the product of the scientists' discipline. So, this model provides a scope to foster a range of higher cognitive abilities among students through science education.

\section{FIESI Model}

The FIESI model was developed with the objective to foster productive thinking among elementary school students with its appropriate syntax, social system and the support system. This model provides a platform for merging process of creative and critical thinking where both the thinking process go hand in hand in a synchronized manner where critical thinking is used to evaluate the creative thinking and thereby providing value and strength to the creative thinking. The model has following five phases to progress viz. Foundation, Ideation, Evaluation, Stabilization and Implication. At the first phase, a knowledge foundation is prepared by the teacher using student centered strategies, then some situations are provided to the students to draw their creative potentials through generating different creative ideas, in the third phase, students evaluate the generated creative ideas to make the ideas feasible through critical thinking, then students try to stabilize the generated ideas and finally imply these stabilized ideas in real life situations. This FIESI model was integrated with the content of science subject. The process of productive thinking can be understood by Figure 1:

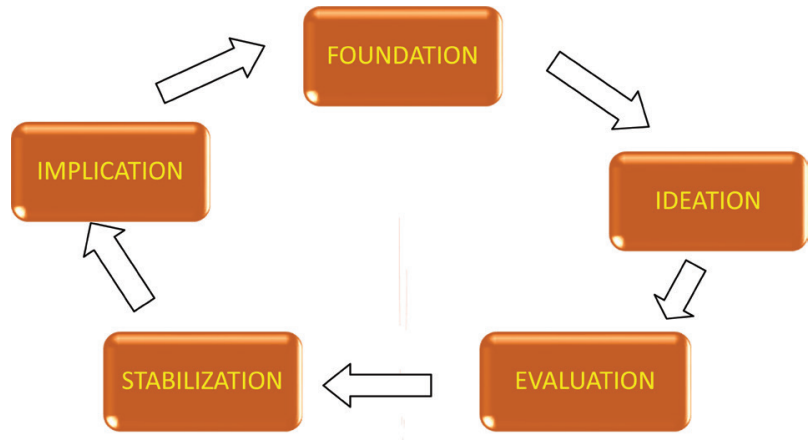

Figure 1: Model of Productive thinking (FIESI).

\section{Objectives}

1. Development of a model for fostering productive thinking among school students. 
2. Implementation of the proposed model for fostering productive thinking among standard VIII students of Kendriya Vidyalayas through the teaching of Science.

3. Studying effectiveness of the proposed model for fostering productive thinking among standard VIII students of Kendriya Vidyalayas through the teaching of Science.

\section{Hypotheses}

11 null hypotheses were formulated.

$\mathbf{H}_{\mathbf{o}}$ (1-10): There is no significant difference between the thinking pattern of students belonging to experiment group and control group for thinking task 1. (Likewise there were 10 null hypothesis for 10 thinking tasks)

Ho11: There is no significant difference between the thinking pattern of students belonging to experiment group and control group considering the average frequency for all the 10 thinking tasks.

\section{Methodology}

Quasi experimental design was used in the present study. Pre-test post-test non equivalent groups design was used for the experimentation. Researchers developed and validated a FIESI model for fostering productive thinking among students with its appropriate syntax, social system and the support system. The developed model was experimented following the said research design.

\section{Population and Sample}

All the students studying in standard VIII of KendriyaVidyalayas in Gujarat, India constituted as the population for the present study. Two Kendriya Vidyalayas were selected purposively from Vadodara City. One school was assigned as the school for experimental group and other school as the school for control group. One section of standard VIII from each school was selected as the class for the sample for the experimental and control group. Students of both the sample classes were made equivalent on the basis of their science achievement (pre-test). The equivalent group consisting of 26 students each for experimental and control group and those 52 students constituted as the sample for the present study.

\section{Tools for Data Collection}

For the present study, researchers developed a productive thinking test based on the content of science subject with the assumption that productive thinking is the last stage of thinking process in a continuous process of thinking starting from reproductive thinking passing through critical and creative thinking through learning, experience and maturation. The test consist of 10 situation specific tasks and was validated by the experts. Each task/item of the test has 4 different alternative responses representing different types of thinking i.e. reproductive thinking, critical thinking, creative thinking and productive thinking in a sequence. The alternatives are arranging in the test on a random manner. The respondents were asked to choose one or more appropriate alternatives for each items as the response. The thinking ability of the respondents for the specific items would be considered having the highest order of thinking from his/her responses. A science achievement was also developed on the basis of the science content of the previous year i.e. standard VII which was used as the pre-test for the purpose of making the experiment and control group equivalent. The test was also validated by the subject experts.

\section{Experiment}

The experiment group was taught science for one academic year, integrating FIESI model with the science content for the purpose of fostering productive thinking along with the knowledge of science. Lesson plans were developed for all the chapters of science keeping in mind the steps of FIESI model and the group was taught by the researchers. During the same period, the control group was taught science through the traditional method of teaching by their subject teachers. At the end of the session, productive thinking test was administered on both the experiment and control groups as post-test.

\section{Analysis of Data}

Collected data were analyzed using Chi-square test as it is a useful method of comparing experimentally obtained result with those to be expected theoretically on some hypothesis (Garrett and Woodworth, 2008). In the present study, the assumption is that the 
results of the experiment group is expected like that of the control group if there is no experiment and hence the result of the control group is considered as the expected frequency ( $\mathrm{fe}$ ) and the result of the experiment group is considered as the observed frequency (fo). Item wise detailed analysis is given in tables 1 to 11 , where reproductive thinking is considered as the lowest order of thinking and productive thinking is considered as the highest order of thinking passing through critical and creative thinking in an increasing order.

From Table 1, the chi-square value for the frequency observed and frequency expected was found to be 28.84 which was found to be greater than the table value for chi-square i.e. 7.815 at 0.05 level of significance with $\mathrm{df}$ of 3 . Hence, the $\mathbf{H}_{\mathrm{o}} \mathbf{1}$ i.e."There is no significant difference between the thinking pattern of students belonging to experiment group and control group for thinking task 1 " is rejected and it can be said that there is a true difference in the thinking pattern of experiment and control group in terms of thinking task 1 .
From Table 2, the chi-square value for the frequency observed and frequency expected was found to be 8.64 which was found to be greater than the table value for chi-square i.e. 7.815 at 0.05 level of significance with df of 3. Hence, the $\mathbf{H}_{\mathrm{o}} \mathbf{2}$ i.e. "There is no significant difference between the thinking pattern of students belonging to experiment group and control group for thinking task 2" is rejected and it can be said that there is a true difference in the thinking pattern of experiment and control group in terms of thinking task 2.

From Table 3, the chi-square value for the frequency observed and frequency expected was found to be 8.02 which was found to be greater than the table value for chi-square i.e. 7.815 at 0.05 level of significance with $\mathrm{df}$ of 3 . Hence, the $\mathbf{H}_{\mathrm{o}} \mathbf{3}$ i.e."There is no significant difference between the thinking pattern of students belonging to experiment group and control group for thinking task 3 " is rejected and it can be said that there is a true difference in the thinking pattern of experiment and control group in terms of thinking task 3 .

Table 1: Frequency wise distribution of students in Experiment group (fo) and Control group (fe) in different pattern of thinking for thinking task 1 .

\begin{tabular}{|l|l|l|l|l|l|l|}
\hline $\begin{array}{l}\text { Thinking } \\
\text { Pattern } \\
\text { Groups } \Omega\end{array}$ & $\begin{array}{l}\text { Reproductive } \\
\text { Thinking }\end{array}$ & $\begin{array}{l}\text { Critical } \\
\text { Thinking }\end{array}$ & $\begin{array}{l}\text { Creative } \\
\text { Thinking }\end{array}$ & $\begin{array}{l}\text { Productive } \\
\text { Thinking }\end{array}$ & Total & $\begin{array}{l}\text { Chi-Square } \\
\text { Value }\end{array}$ \\
\hline Experiment (fo) & 1 & 11 & 6 & 8 & 26 & 28.84 \\
\hline Control (fe) & 11 & 6 & 7 & 2 & 26 & \\
\hline
\end{tabular}

Table 2: Frequency wise distribution of students in Experiment group(fo) and Control group (fe) in different pattern of thinking for thinking task 2 .

\begin{tabular}{|l|l|l|l|l|l|l|}
\hline $\begin{array}{l}\text { Thinking } \\
\text { Pattern } \\
\text { Groups } \Rightarrow\end{array}$ & $\begin{array}{l}\text { Reproductive } \\
\text { Thinking }\end{array}$ & $\begin{array}{l}\text { Critical } \\
\text { Thinking }\end{array}$ & $\begin{array}{l}\text { Creative } \\
\text { Thinking }\end{array}$ & $\begin{array}{l}\text { Productive } \\
\text { Thinking }\end{array}$ & Total & $\begin{array}{l}\text { Chi-Square } \\
\text { Value }\end{array}$ \\
\hline Experiment (fo) & 7 & 2 & 3 & 14 & 26 & 8.64 \\
\hline Control (fe) & 7 & 2 & 9 & 8 & 26 & \\
\hline
\end{tabular}

Table 3: Frequency wise distribution of students in Experiment group (fo) and Control group (fe) in different pattern of thinking for thinking task 3 .

\begin{tabular}{|l|l|l|l|l|l|l|}
\hline $\begin{array}{l}\text { Thinking } \\
\text { Pattern } \\
\text { Groups }\end{array}$ & $\begin{array}{l}\text { Reproductive } \\
\text { Thinking }\end{array}$ & $\begin{array}{l}\text { Critical } \\
\text { Thinking }\end{array}$ & $\begin{array}{l}\text { Creative } \\
\text { Thinking }\end{array}$ & $\begin{array}{l}\text { Productive } \\
\text { Thinking }\end{array}$ & Total & $\begin{array}{l}\text { Chi-Square } \\
\text { Value }\end{array}$ \\
\hline Experiment (fo) & 6 & 3 & 2 & 15 & 26 & 8.02 \\
\hline Control (fe) & 13 & 3 & 1 & 9 & 26 & \\
\hline
\end{tabular}


From Table 4, the chi-square value for the frequency observed and frequency expected was found to be 17.46 which was found to be greater than the table value for chi-square i.e. 7.815 at 0.05 level of significance with $\mathrm{df}$ of 3 . Hence, the $\mathbf{H}_{\mathrm{o}} \mathbf{4}$ i.e."There is no significant difference between the thinking pattern of students belonging to experiment group and control group for thinking task 4" is rejected and it can be said that there is a true difference in the thinking pattern of experiment and control group in terms of thinking task 4 .

From Table 5, the chi-square value for the frequency observed and frequency expected was found to be 49.29 which was found to be greater than the table value for chi-square i.e. 7.815 at 0.05 level of significance with $\mathrm{df}$ of 3 . Hence, the $\mathbf{H}_{\mathrm{o}} \mathbf{5}$ i.e."There is no significant difference between the thinking pattern of students belonging to experiment group and control group for thinking task 5 " is rejected and it can be said that there is a true difference in the thinking pattern of experiment and control group in terms of thinking task 5 .
From Table 6, the chi-square value for the frequency observed and frequency expected was found to be 20.31 which was found to be greater than the table value for chi-square i.e. 7.815 at 0.05 level of significance with $\mathrm{df}$ of 3 . Hence, the $\mathbf{H}_{\mathrm{o}} \mathbf{6}$ i.e."There is no significant difference between the thinking pattern of students belonging to experiment group and control group for thinking task 6 " is rejected and it can be said that there is a true difference in the thinking pattern of experiment and control group in terms of thinking task 6 .

From Table 7 , the chi-square value for the frequency observed and frequency expected was found to be 60.73 which was found to be greater than the table value for chi-square i.e. 7.815 at 0.05 level of significance with $\mathrm{df}$ of 3 . Hence, the $\mathbf{H}_{\mathrm{o}} 7$ i.e."There is no significant difference between the thinking pattern of students belonging to experiment group and control group for thinking task 7 " is rejected and it can be said that there is a true difference in the thinking pattern of experiment and control group in terms of thinking task 7.

Table 4: Frequency wise distribution of students in Experiment group (fo) and Control group (fe) in different pattern of thinking for thinking task 4.

\begin{tabular}{|l|l|l|l|l|l|l|}
\hline $\begin{array}{l}\text { Thinking } \\
\text { Pattern } \\
\text { Groups } \Rightarrow\end{array}$ & $\begin{array}{l}\text { Reproductive } \\
\text { Thinking }\end{array}$ & $\begin{array}{l}\text { Critical } \\
\text { Thinking }\end{array}$ & $\begin{array}{l}\text { Creative } \\
\text { Thinking }\end{array}$ & $\begin{array}{l}\text { Productive } \\
\text { Thinking }\end{array}$ & Total & $\begin{array}{l}\text { Chi-Square } \\
\text { Value }\end{array}$ \\
\hline Experiment (fo) & 3 & 3 & 8 & 12 & 26 & 17.46 \\
\hline Control (fe) & 11 & 5 & 3 & 7 & 26 & \\
\hline
\end{tabular}

Table 5: Frequency wise distribution of students in Experiment group (fo) and Control group (fe) in different pattern of thinking for thinking task 5 .

\begin{tabular}{|l|l|l|l|l|l|l|}
\hline $\begin{array}{l}\text { Thinking } \\
\text { Pattern } \\
\text { Groups }\end{array}$ & $\begin{array}{l}\text { Reproductive } \\
\text { Thinking }\end{array}$ & $\begin{array}{l}\text { Critical } \\
\text { Thinking }\end{array}$ & $\begin{array}{l}\text { Creative } \\
\text { Thinking }\end{array}$ & $\begin{array}{l}\text { Productive } \\
\text { Thinking }\end{array}$ & Total & $\begin{array}{l}\text { Chi-Square } \\
\text { Value }\end{array}$ \\
\hline Experiment (fo) & 5 & 1 & 9 & 11 & 26 & 49.29 \\
\hline Control (fe) & 12 & 7 & 5 & 2 & 26 & \\
\hline
\end{tabular}

Table 6: Frequency wise distribution of students in Experiment group (fo) and Control group (fe) in different pattern of thinking for thinking task 6.

\begin{tabular}{|l|l|l|l|l|l|l|}
\hline $\begin{array}{l}\text { Thinking } \\
\text { Pattern } \\
\text { Groups }\end{array}$ & $\begin{array}{l}\text { Reproductive } \\
\text { Thinking }\end{array}$ & $\begin{array}{l}\text { Critical } \\
\text { Thinking }\end{array}$ & $\begin{array}{l}\text { Creative } \\
\text { Thinking }\end{array}$ & $\begin{array}{l}\text { Productive } \\
\text { Thinking }\end{array}$ & Total & $\begin{array}{l}\text { Chi-Square } \\
\text { Value }\end{array}$ \\
\hline Experiment (fo) & 3 & 7 & 7 & 9 & 26 & 20.31 \\
\cline { 1 - 2 } & 7 & 3 & 13 & 3 & 26 & \\
\hline
\end{tabular}


Table 7: Frequency wise distribution of students in Experiment group (fo) and Control group (fe) in different pattern of thinking for thinking task 7.

\begin{tabular}{|l|l|l|l|l|l|l|}
\hline $\begin{array}{l}\text { Thinking } \\
\text { Pattern } \\
\text { Groups } \Rightarrow\end{array}$ & $\begin{array}{l}\text { Reproductive } \\
\text { Thinking }\end{array}$ & $\begin{array}{l}\text { Critical } \\
\text { Thinking }\end{array}$ & $\begin{array}{l}\text { Creative } \\
\text { Thinking }\end{array}$ & $\begin{array}{l}\text { Productive } \\
\text { Thinking }\end{array}$ & Total & $\begin{array}{l}\text { Chi-Square } \\
\text { Value }\end{array}$ \\
\hline Experiment (fo) & 5 & 6 & 6 & 9 & 26 & 60.73 \\
\hline Control (fe) & 11 & 7 & 7 & 1 & 26 & \\
\hline
\end{tabular}

From Table 8, the chi-square value for the frequency observed and frequency expected was found to be 17.44 which was found to be greater than the table value for chi-square i.e. 7.815 at 0.05 level of significance with $\mathrm{df}$ of 3 . Hence, the $\mathbf{H}_{\mathrm{o}} \mathbf{8}$ i.e. "There is no significant difference between the thinking pattern of students belonging to experiment group and control group for thinking task 8 " is rejected and it can be said that there is a true difference in the thinking pattern of experiment and control group in terms of thinking task 8.

From Table 9, the chi-square value for the frequency observed and frequency expected was found to be 33.7 which was found to be greater than the table value for chi-square i.e. 7.815 at 0.05 level of significance with $\mathrm{df}$ of 3 . Hence, the $\mathbf{H}_{\mathbf{o}} \mathbf{9}$ i.e. "There is no significant difference between the thinking pattern of students belonging to experiment group and control group for thinking task 9" is rejected and it can be said that there is a true difference in the thinking pattern of experiment and control group in terms of thinking task 9.

From Table 10, the chi-square value for the frequency observed and frequency expected was found to be 16.14 which was found to be greater than the table value for chi-square i.e. 7.815 at 0.05 level of significance with $\mathrm{df}$ of 3 . Hence, the $\mathbf{H}_{\mathbf{o}} \mathbf{1 0}$ i.e." There is no significant difference between the thinking pattern of students belonging to experiment group and control group for thinking task 10 " is rejected and it can be said that there is a true difference in the thinking pattern of experiment and control group in terms of thinking task 10.

Table 8: Frequency wise distribution of students in Experiment group (fo) and Control group (fe) in different pattern of thinking for thinking task 8 .

\begin{tabular}{|l|l|l|l|l|l|l|}
\hline $\begin{array}{l}\text { Thinking } \\
\text { Pattern } \\
\text { Groups } \Rightarrow\end{array}$ & $\begin{array}{l}\text { Reproductive } \\
\text { Thinking }\end{array}$ & $\begin{array}{l}\text { Critical } \\
\text { Thinking }\end{array}$ & $\begin{array}{l}\text { Creative } \\
\text { Thinking }\end{array}$ & $\begin{array}{l}\text { Productive } \\
\text { Thinking }\end{array}$ & Total & $\begin{array}{l}\text { Chi-Square } \\
\text { Value }\end{array}$ \\
\hline Experiment (fo) & 2 & 7 & 12 & 5 & 26 & 17.44 \\
\hline Control (fe) & 11 & 7 & 5 & 3 & 26 & \\
\hline
\end{tabular}

Table 9: Frequency wise distribution of students in Experiment group (fo) and Control group (fe) in different pattern of thinking for thinking task 9.

\begin{tabular}{|l|l|l|l|l|l|l|}
\hline $\begin{array}{l}\text { Thinking } \\
\text { Pattern } \\
\text { Groups } \Rightarrow\end{array}$ & $\begin{array}{l}\text { Reproductive } \\
\text { Thinking }\end{array}$ & $\begin{array}{l}\text { Critical } \\
\text { Thinking }\end{array}$ & $\begin{array}{l}\text { Creative } \\
\text { Thinking }\end{array}$ & $\begin{array}{l}\text { Productive } \\
\text { Thinking }\end{array}$ & Total & $\begin{array}{l}\text { Chi-Square } \\
\text { Value }\end{array}$ \\
\hline Experiment (fo) & 3 & 10 & 6 & 7 & 26 & 33.7 \\
\hline Control (fe) & 7 & 12 & 6 & 1 & 26 & \\
\hline
\end{tabular}

Table 10: Frequency wise distribution of students in Experiment group(fo) and Control group (fe) in different pattern of thinking for thinking task 10 .

\begin{tabular}{|l|l|l|l|l|l|l|}
\hline $\begin{array}{l}\text { Thinking } \\
\text { Pattern } \\
\text { Groups } \square\end{array}$ & $\begin{array}{l}\text { Reproductive } \\
\text { Thinking }\end{array}$ & $\begin{array}{l}\text { Critical } \\
\text { Thinking }\end{array}$ & $\begin{array}{l}\text { Creative } \\
\text { Thinking }\end{array}$ & $\begin{array}{l}\text { Productive } \\
\text { Thinking }\end{array}$ & Total & $\begin{array}{l}\text { Chi-Square } \\
\text { Value }\end{array}$ \\
\hline Experiment (fo) & 2 & 7 & 12 & 5 & 26 & 16.14 \\
\hline Control (fe) & 9 & 9 & 5 & 3 & 26 & \\
\hline
\end{tabular}


Table 11: Average frequency wise distribution of students in Experiment group (fo) and Control group (fe) in different pattern of thinking for average of all thinking tasks.

\begin{tabular}{|l|l|l|l|l|l|l|}
\hline $\begin{array}{l}\text { Thinking } \\
\text { Pattern } \\
\text { Groups 』 }\end{array}$ & $\begin{array}{l}\text { Reproductive } \\
\text { Thinking }\end{array}$ & $\begin{array}{l}\text { Critical } \\
\text { Thinking }\end{array}$ & $\begin{array}{l}\text { Creative } \\
\text { Thinking }\end{array}$ & $\begin{array}{l}\text { Productive } \\
\text { Thinking }\end{array}$ & Total & $\begin{array}{l}\text { Chi-Square } \\
\text { Value }\end{array}$ \\
\hline Experiment (fo) & 3.7 & 5.7 & 8.2 & 8.4 & 26 & 8.95 \\
\hline Control (fe) & 9.9 & 6.1 & 6 & 4 & 26 & \\
\hline
\end{tabular}

From Table 11, the chi-square value for the frequency observed and frequency expected was found to be 8.95 which was found to be greater than the table value for chi-square i.e. 7.815 at 0.05 level of significance with $\mathrm{df}$ of 3 . Hence, the $\mathbf{H}_{\mathbf{o}} \mathbf{1 1}$ i.e. "There is no significant difference between the average thinking pattern of students belonging to experiment group and control group considering the average frequency for all the 10 thinking tasks" is rejected and it can be said that there is a true difference in the thinking pattern of experiment and control group in terms of the average frequency taking all the items together.

Further, analyzing the frequency distribution of experiment and the control group students across different thinking patterns from all the tables 1 to 11 , it can be inferred that more students are there in the experiment group towards higher order productive thinking, whereas, there are more students towards lower order reproductive thinking and less students towards productive thinking in the control group, which may be due to the influence of FIESI model that promotes more students towards productive thinking through critical and creative thinking.

\section{Major Findings and Discussion}

Significant differences were observed in the thinking pattern of students in experiment and control groups in all the 10 thinking tasks individually and as a whole. More number of students were found in the experiment group towards higher order productive thinking through critical and creative thinking, whereas, more number of students were observed in the control group towards the lower order reproductive thinking. Hence, teaching science through FIESI model was found effective in fostering productive thinking of standard VIII students of Kendriya Vidyalaya in comparison to the traditional method of teaching. Along with these major findings, it was also observed that quite a good number of students showed their critical and creative thinking pattern in comparison to their control group counterpart.

The findings of the present study revealed that teaching through FIESI model will lead students towards higher order thinking like critical, creative and productive thinking which is also supported by the studies conducted by Kumari (2014) and Sridevi (2016) where six thinking hats technique was used for enhancing problem solving abilities, lateral thinking and general creativity of students. Studies conducted by Patel (1988) and Schuler (1974) also supported the findings of the present study. In their studies, productive thinking programmes were found effective in developing creativity of students. The findings of the present study is also supported by the studies of Reema (2016) and Kachhia (1990) where the researchers found CoRT thinking programme effective in developing creativity in elementary school students. The study conducted by Chin (2006) is directly related to the present study where the researcher proved the effectiveness of questioning in promoting productive thinking. In the present study, the researchers also used a lot of questioning strategy in the FIESI model to develop creativity among students. From the findings and discussion of the present study, it can be said that strategies, models, programmes designed and implemented in a planned way can help student to develop higher order thinking. In the present study, the developed FIESI model was proved to foster higher order thinking skills like critical, creative and productive thinking among elementary students by integrating it with the content of science and further researches are needed to integrate this model with other subjects and in higher classes to foster higher order thinking skills among students.

\section{Conclusion}

Productive thinking is the ability to be both creative and critical while solving a problem creatively. It 
provides a platform to be away from the reproductive thinking or rote learning as we know it is the prevalent condition of our classroom today. The process of productive thinking in the FIESI model starts from foundation to implication through ideation, evaluation and stabilization. Through this cycle, students learn higher order thinking skills like analysis, synthesis, evaluation, decision making and implementing. The result of the study shows that teaching science through the integration of FIESI model is effective in fostering productive thinking among standard VIII students of Kendriya Vidyalayas. This model may be useful for teaching other school subjects at different levels. This need lots of efforts by research taking different subjects at different levels of the school education for the enhancement of higher order thinking among students.

\section{References}

Birch, H.G., \& Rabinowitz, H.S. (1951). The negative effect of previous experience on productive thinking. Journal of Experimental Psychology, 41(2), 121-125. https://doi.org/10.1037/h0062635

Chin, C. (2007). Teacher questioning in science classrooms: Approaches that stimulate productive thinking. Journal of Research in Science Teaching, 44(6), 815843. https://doi.org/10.1002/tea.20171

Gill, T.K. (1989). Effect of training strategies on CPS skills and cerebral dominance in relation to intelligence personality and cognitive style. Thesis, Department of Education, Panjab University. Retrieved from

https://shodhganga.inflibnet.ac.in/handle/10603/79868

Garrette, H.E. (2017). Statistics in psychology and education (6th ed.). Sujeet publication.

Kachhia, A.G. (1990). Adaptation of the cort thinking programme and to study its effect on the children's creativity. Thesis, Department of Education, Sardar Patel University. Retrieved from https://shodhganga. inflibnet.ac.in/handle/10603/75430

Kingdon, G.G. (2007). The progress of school education in India. Oxford Review of Economic Policy, 23(2), 168-195. https://doi.org/10.1093/oxrep/grm015

Kumari, S. (2016). Effectiveness of six thinking hats strategy on the development of parallel thinking lateral thinking and general creativity in high school students. Thesis, Department of Education, Kurukshetra University. Retrieved from http://shodhganga. inflibnet.ac.in:8080/jspui/handle/10603/76504
Mayer, R.E. (2002). Rote versus Meaningful Learning. Theory into Practice, 41(4), 226-232. https://doi.org/10.1207/s15430421tip4104_4

Government of India, Ministry of Human Resource and Development (1986). National Education Policy 1986. New Delhi: MHRD. Retrieved from https:// www.mhrd.gov.in/sites/upload_files/mhrd/files/ upload_document/NPE86-mod92.pdf

Government of India, Ministry of Human Resource and Development (2020). National Education Policy 2020. New Delhi: MHRD.

National Council of Educational Research and Training (2005). National Curriculum Framework 2005. New Delhi: NCERT. Retrieved from: https://ncert.nic.in/ pdf/nc-framework/nf2005-english.pdf

National Council of Educational Research and Training (2006). Position paper on national focus group on teaching of science. New Delhi: NCERT. Retrieved from https://ncert.nic.in/pdf/focus-group/science.pdf

Newton, L. (2017). Questioning: a window on productive thinking. Ulm: International Centre for Innovation in Education (ICIE).

Patel, D.D. (1988). A study of productive thinking programme in geography on creativity of students of class IX. Thesis, Department of Education, Sardar Patel University. Retrieved from https://hdl.handle.net/10603/75523

Pahuja, R. (2016). Effectiveness of thinking training programmeCoRT on the basis of creativity. Thesis, Department of Community Education and Development, Punjab University. Retrieved from https://shodhganga.inflibnet.ac.in/ handle/10603/207226

Saido, G.M., Siraj, S., Nordin, A.B.B., \& Al_Amedy, O.S. (2015). Higher order thinking skills among secondary school students in science learning. The Malaysian Online Journal of Educational Science, 3(3),13-20.

Schuler (1974). The effectiveness of productive thinking programme. Retrieved from https://Files.eric.ed.gov/ fulltext/ED103479.pdf

Sridevi, P. (2016). Effectiveness of six thinking hats technique on the problem solving ability of B.Ed. teacher trainee: An experimental study. Thesis, Department of Education, Manonmaniam Sundaranar University. Retrieved from https://hdl.handle.net/10603/175819

World Economic Forum (2016). The Future of Jobs, Employment, Skills and Workforce Strategy for the Fourth Industrial Revolution. Geneva: World Economic Forum. 


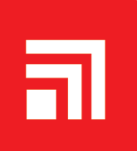 \\ CHITKARA}

\section{Issues and Ideas in Education}

Chitkara University, Saraswati Kendra, SCO 160-161, Sector 9-C, Chandigarh, 160009, India

Volume 8, Issue 2

September 2020

ISSN 2320-7655

Copyright: [C 2020 Ashutosh Biswal and Kamakshi Raipure] This is an Open Access article published in Issues and Ideas in Education (Issues Ideas Educ.) by Chitkara University Publications. It is published with a Creative Commons Attribution- CC-BY 4.0 International License. This license permits unrestricted use, distribution, and reproduction in any medium, provided the original author and source are credited. 